\title{
Thermal behavior, spectroscopic study and evolved gas analysis (EGA) during pyrolysis of picolinic acid, sodium picolinate and its light trivalent lanthanide complexes in solid state
}

\author{
A.L.C.S. do Nascimento ${ }^{a}$, J.A. Teixeira ${ }^{a}$, W.D.G. Nunes ${ }^{a}$, F.X. Campos ${ }^{a}$, O. Treu-Filho ${ }^{a}$, \\ F.J. Caires ${ }^{\mathrm{b}}, \mathrm{M}$. Ionashiro ${ }^{\mathrm{a}, *}$ \\ a Instituto de Química, Universidade Estadual Paulista, CP 355, 14801-970 Araraquara, SP, Brazil \\ b FACULDADE DE CIÊNCIAS, UNESP-Univ., Estadual Paulista, Campus Bauru, Departamento de Química, Bauru, SP 17033-260, Brazil
}

\section{A R T I C L E I N F O}

\section{Article history:}

Received 16 October 2015

Received in revised form 18 January 2016

Accepted 23 January 2016

Available online 15 February 2016

\section{Keywords:}

Light trivalent lanthanides

Picolinate

Pyrolysis

Density functional theory (DFT)

Evolved gases analysis (EGA)

\begin{abstract}
A B S T R A C T
Synthesis, characterization, and thermal behavior of light trivalent lanthanide picolinate (La-Gd, except $\mathrm{Pm}$ ) as well as the thermal behavior of picolinic acid and its sodium salt were investigated employing elemental analysis, complexometry, differential scanning calorimetry (DSC), simultaneous thermogravimetry and differential scanning calorimetry (TG-DSC), infrared spectroscopy (FTIR), X-ray power diffractometry, and evolved gas analysis (EGA) for TG-DSC coupled to FTIR. All the synthesized compounds were obtained in the anhydrous state and the thermal decomposition in dynamic dry air atmosphere occured in a single step or two consecutive steps with formation of the respective oxides, $\mathrm{CeO}_{2}, \mathrm{Pr}_{6} \mathrm{O}_{11}$ and $\mathrm{Ln}_{2} \mathrm{O}_{3}(\mathrm{Ln}=\mathrm{La}, \mathrm{Nd}$ to $\mathrm{Gd})$. In dynamic dry nitrogen atmosphere the thermal decomposition occured in two or three consecutive steps and mass loss was observed up to $1000^{\circ} \mathrm{C}$. The EGA data allowed the identification of gaseous products evolved during pyrolysis and oxidative decomposition. The results of density functional theory (DFT) and FTIR also provided information on the ligand's denticity.
\end{abstract}

(c) 2016 Elsevier B.V. All rights reserved.

\section{Introduction}

The pyridine 2-carboxylic acid, usually known as picolinic acid is a pyridine derivative compound with a carboxylic acid group at position 2 carbon of pyridine ring. It is an essential substance for the metabolic process present in several foods of the human diet and also a safe and inexpensive pharmaceutical with chelating activity for metal ions [1]. It is a natural product of L-tryptophan degradation or synthesized form L-tryptophan, via a sequent side branch of the kynurenine pathway [1,2], this acid has been studied for many pharmacological applications, presenting antimicrobial $[1,3,4]$, antiviral, cytotoxic and apoptotic activities [5] and inhibition of HIV-1 [6] among other caracteristics.

The extant literature includes studies that have examined the association of the picolinic N-oxide forming with bivalent transition metals ions [7] and trivalent lanthanide ions [8,9]. Furthermore, lanthanide complexes with picolinic acid forming a mixed-ligand compound, with 2,6-pyridine dicarboxylic acid [10] and glutaric acid [11] were investigated. After a literature review, no systematic study of thermal behavior of the lanthanide picolinates (except the lanthanum, praseodymium and neodymium) was found [12]. Few research papers describe the synthesis of similar compounds. Some of them investigate the coordination properties of europium complex with picolinic acid [13]; the crystal structure, magnetic and photoluminescent properties of the neodymium and samarium compounds [14]; the magnetic and spectral properties of the La (III), Nd (III), Sm (III) and Eu (III) compounds [15]; and the preparation and characterization of some rare earth picolinate complex [16].

Thus the present paper aims to investigate the thermal behavior of picolinic acid and its sodium salt, as well as to prepare solid-state compounds of light trivalent lanthanide picolinates and to characterize and investigate by means of complexometry, elemental analysis, X-ray diffractometry, infrared spectroscopy (FTIR), theoretical calculation based on density functional theory, simultaneous thermogravimetry and differential scanning calorimetry (TG-DSC) in dry air and $\mathrm{N}_{2}$ atmospheres, differential scanning calorimetry (DSC) also in both atmospheres and TG-DSC coupled to FTIR.

\footnotetext{
* Corresponding author.

E-mail address: massaoi@yahoo.com.br (M. Ionashiro).
} 


\section{Materials and methods}

The picolinic acid, $\mathrm{C}_{6} \mathrm{H}_{4} \mathrm{NO}_{2}$ with $99.5 \%$ purity was obtained from Sigma and was used without further purification. An aqueous solution of sodium picolinate $0.1 \mathrm{~mol} \mathrm{~L}^{-1}$ was prepared by neutralization of an aqueous solution of picolinic acid with sodium hydroxide solution $0.1 \mathrm{~mol} \mathrm{~L}^{-1}$. Aqueous solutions of lanthanide chlorides $0.1 \mathrm{~mol} \mathrm{~L}^{-1}$ were prepared from the corresponding metal oxides (except for cerium) by treatment with concentrated hydrochloric acid, following the procedure described. Gigante et al. [17]. Cerium (III) was used as its chloride and $0.1 \mathrm{~mol} \mathrm{~L}^{-1}$ aqueous solution of this ion was prepared by direct weighing of the salt.

The solid-state lanthanide picolinates were prepared by synthetic route using urea. Stoichiometric calculations were performed to obtain $1 \mathrm{~g}$ of the compounds. For all of them a slow precipitation in homogeneous medium was made using slight excess of urea as neutralizing agent, except for the europium and gadolinium compounds, in which the addition of urea was stoichiometric. Aqueous solutions of lanthanide chlorides were added in $400 \mathrm{~mL}$ beaker, with their respective amounts of picolinic acid and then solid urea was added to solution. The beakers were sealed with perforated aluminum foil, and kept in a forced air circulation oven at $90^{\circ} \mathrm{C}$. At this temperature, urea decomposes slowly, neutralizing picolinic acid, leading to the slow precipitation of the compounds. The precipitates were then filtered and washed with distilled water until elimination of chloride ions (qualitative test with $\mathrm{AgNO}_{3} / \mathrm{HNO}_{3}$ ), dried at $50^{\circ} \mathrm{C}$ in a forced circulation air oven during $24 \mathrm{~h}$ and kept in a desiccator over anhydrous calcium chloride.

Europium and gadolinium compounds were also prepared using slight excess of urea, however binary compounds were not obtained, probably due to increase of the solubility with the increase of atomic number of the lanthanides and with slight excess of urea occurs an increase in the solution $\mathrm{pH}$, favoring the formation of basic picolinates.

Metal ions and picolinate contents in the compounds were determined from TG curves obtained in air atmosphere. The metal ions contents were also determined by complexometry with standard EDTA solution, using xylenol orange as indicator, after igniting the compounds to the respective oxides and their dissolution in hydrochloric acid solution [18,19].

The X-ray powder patterns were obtained by using a Siemens D$5000 \mathrm{X}$-ray diffractometer, employing $\mathrm{CuK} \alpha$ radiation $(\lambda=1.541 \AA$ ) and setting of $40 \mathrm{kV}$ and $20 \mathrm{~mA}$.

Hydrogen, carbon and nitrogen contents were determined by stoichiometric calculations, based on the mass losses of the TG curves obtained in air atmosphere, since the thermal decomposition of the compound leads to formation of residues with known stoichiometry (oxides). Microanalysis was also used in order to establish the stoichiometry from CE instruments an EA 1110CHNSO Elemental Analyzer.

Simultaneous thermogravimetry and differential scanning calorimetry (TG-DSC) curves were obtained in a TG-DSC STAR ${ }^{\mathrm{e}}$ system, from Mettler Toledo. The purge gas was both dry air and $\mathrm{N}_{2}$, flow rate of $50 \mathrm{~mL} \mathrm{~min}^{-1}$. A heating rate of $10^{\circ} \mathrm{C} \mathrm{min}^{-1}$ was adopted, with samples weighing about $10.4 \mathrm{mg}$. Alumina crucibles were used for recording the TG-DSC curves.

The DSC curves were obtained using a DSC Q10 from TA instruments. The purge gas was both dry air and $\mathrm{N}_{2}$, flow rate of $50 \mathrm{~mL} \mathrm{~min}^{-1}$. Heating rates of 5 and $10^{\circ} \mathrm{C} \mathrm{min}^{-1}$ were adopted for the picolinic acid and its sodium salt, respectively, with sample weighing about $2 \mathrm{mg}$. Aluminum crucible with perforated cover was used for recording the DSC curves.

The detection of the gaseous products was carried out coupling the TG-DSC Mettler Toledo furnace gas outlet to a FTIR spectrophotometer Nicolet equipped with a gas cell and DTGS KBr detector. The gaseous products from the thermal decomposition were carried towards the gas cell (heated at $250^{\circ} \mathrm{C}$ ) by a stainless steel transfer line $\left(120 \mathrm{~cm}, 3 \mathrm{~mm}\right.$ internal diameter, heated at $\left.200^{\circ} \mathrm{C}\right)$ purged with dry air and $\mathrm{N}_{2}$ gas (both, $50 \mathrm{~mL} \mathrm{~min}^{-1}$ ). The FTIR spectra were recorded with 16 scans per spectrum at a resolution of $4 \mathrm{~cm}^{-1}$.

\subsection{Computational details}

The quantum chemical approach used to determine the molecular structures was Becke three parameter hybrid theory [20] using the Lee-Yang-Par (LYP) correlation functional [21], and the basis sets used for calculations were: $\left[{ }^{4} \mathrm{~s}\right]$ for $\mathrm{H}\left({ }^{2} \mathrm{~S}\right)[22],\left[{ }^{5} \mathrm{~s}^{4} \mathrm{p}\right]$ for $\mathrm{C}\left({ }^{3} \mathrm{P}\right)$, $\mathrm{N}\left({ }^{4} \mathrm{~S}\right)$ and $\mathrm{O}\left({ }^{3} \mathrm{P}\right)$ [22], [10s6p] and [17s11p7d] for La (2D) [23]. The diffuse functions for the lanthanum atom (2D) were calculated according to the procedure described in [22] and these values are: $\alpha s=0.00669534, \alpha p=0.079333735, \alpha d=0.096432865$.

In order to better describe the properties of the compound in the implementation of the calculations, it was necessary to include polarization functions [22,23] for all atoms of the compound.

The polarization functions are: $\alpha \mathrm{p}=0.33353749$ for $\mathrm{H}(2 \mathrm{~S})$, $\alpha d=0.72760279, \alpha d=0.35416230$ and $\alpha d=0.36059494$ for $C(3 P)$, $\mathrm{N}(4 \mathrm{~S})$ and $\mathrm{O}(3 \mathrm{P})$ respectively, and $\alpha \mathrm{f}=0.36935391$ for $\mathrm{La}(2 \mathrm{D})$ atoms. The role of a basis set is a crucial point in theoretical studies of metal complexes, since the description of the configuration of the metal in the complex differs from the neutral state. The performed molecular calculations in this study were done using the Gaussian 09 routine [24].

The theoretical infrared spectrum was calculated using a harmonic field [25] based on C1 symmetry (electronic state 1A). Frequency values (not scaled), relative intensities, assignments, and description of vibrational modes are presented. The crystal geometry of the $\mathrm{La}\left(\mathrm{C}_{6} \mathrm{H}_{4} \mathrm{NO}_{2}\right)_{3}$ was proposed based on Ref. [26] and it was optimized using Berny Algorithm [27]. The calculations of vibrational frequencies were also implemented to determine whether an optimized geometry constitutes minimum or saddle points. The principal infrared active fundamental modes assignments and descriptions were done by the GaussView 5.0.8 W graphics routine [28].

\section{Results and discussion}

\subsection{Picolinic acid}

The TG-DSC and DSC curves of picolinic acid in dynamic dry air and nitrogen atmospheres are shown in Fig. 1 as a-b and $a^{*}-b^{*}$, respectively. In both atmospheres the TG-DSC curves show total mass loss in a single step between $110-173^{\circ} \mathrm{C}$ and an endothermic event at $120^{\circ} \mathrm{C}$ (air) or $127^{\circ} \mathrm{C}\left(\mathrm{N}_{2}\right)$, attributed to sublimation, followed by two endothermic peaks at 142 and $170^{\circ} \mathrm{C}$ (air) or 141 and $170^{\circ} \mathrm{C}\left(\mathrm{N}_{2}\right)$, attributed to melting and thermal decomposition of the compound, respectively, and the last two thermal events in agreement with Allan et al. [29]. Sublimation fallowed by melting was observed when sample of the compound was heated in a glass tube.

In both atmospheres the DSC curves also show two endothermic peaks at 138 and $200^{\circ} \mathrm{C}$ (air) or 139 and $213^{\circ} \mathrm{C}\left(\mathrm{N}_{2}\right)$, attributed to melting and thermal decomposition of the compound, respectively. The difference in the melting and thermal decomposition temperatures observed in the TG-DSC and DSC curves, is due to the experimental conditions that were not the same, as previously reported [30].

\subsection{Sodium picolinate}

For sodium picolinate the TG-DSC and DSC curves in dynamic dry air and nitrogen atmospheres are shown in Fig. 2 as a-b and 

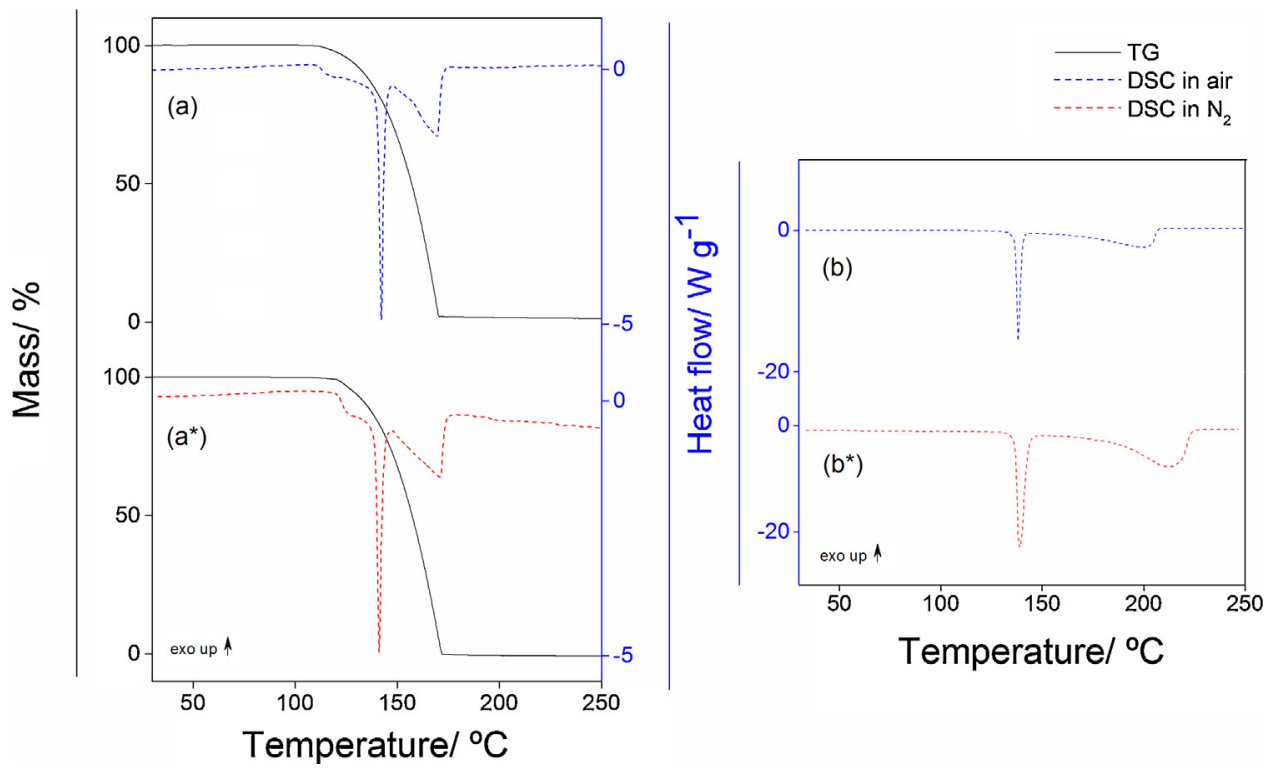

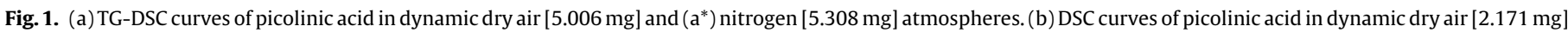
and $\left(\mathrm{b}^{*}\right)$ nitrogen $[2.744 \mathrm{mg}]$ atmospheres.
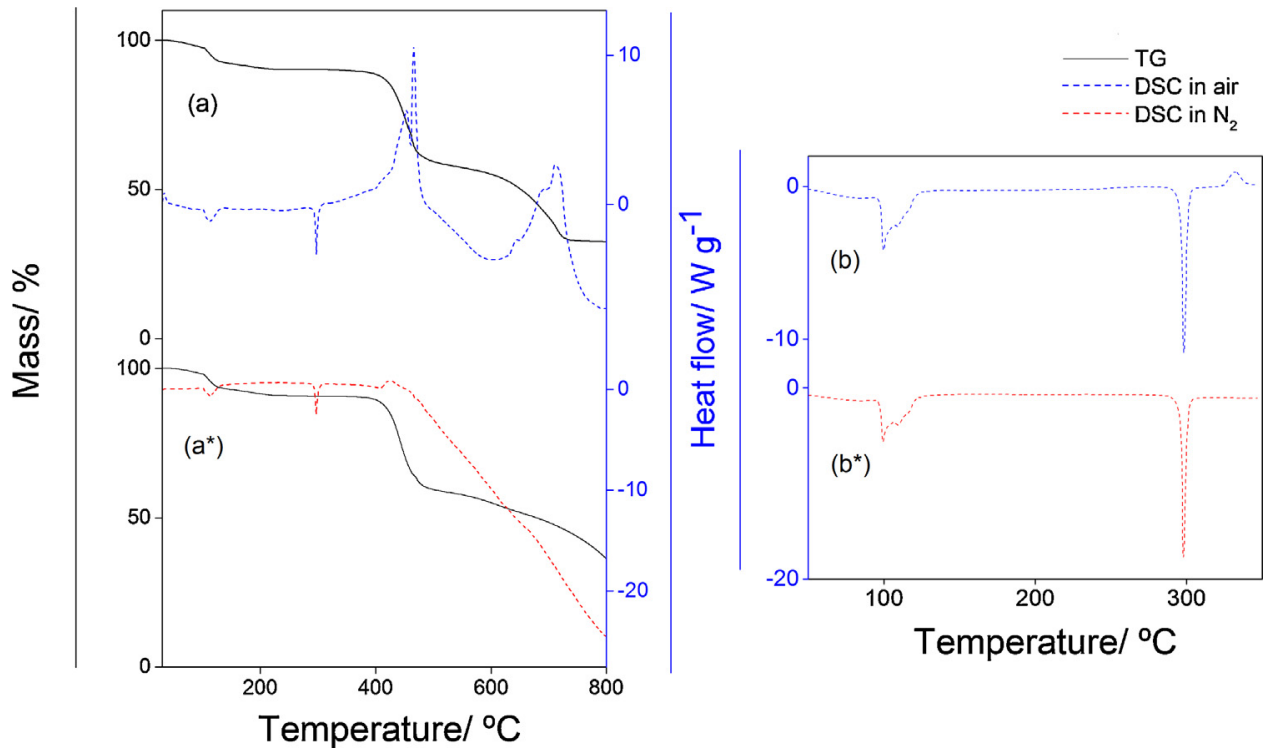

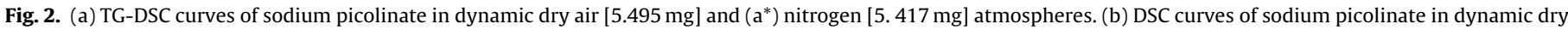
air [2.240 mg] and $\left(b^{*}\right)$ nitrogen $[2.889 \mathrm{mg}]$ atmospheres.

$a^{*}-b^{*}$, respectively. There was mass loss between $40-230^{\circ} \mathrm{C}$ (air) and $45-240{ }^{\circ} \mathrm{C}\left(\mathrm{N}_{2}\right)$, corresponding to an endothermic peak at $115^{\circ} \mathrm{C}$ with loss of $0.8 \mathrm{H}_{2} \mathrm{O}$, in both atmospheres. The TG curve suggests that the dehydration occurs in three overlapping steps, with the first and the third processes occurring slowly and the second occurring quickly.

In air atmosphere the anhydrous compound is stable up to $350{ }^{\circ} \mathrm{C}$ and above this temperature the mass losses occur between $350-480^{\circ} \mathrm{C}$ and $480-760{ }^{\circ} \mathrm{C}$, with loss of $28.90 \%$ and $28.89 \%$, respectively corresponding to exothermic peaks at 450 and $470{ }^{\circ} \mathrm{C}$. These are attributed to oxidation of the organic matter and/or of the gaseous products evolved during the thermal decomposition and exothermic peaks at $715^{\circ} \mathrm{C}$ with shoulder at 645 and $695^{\circ} \mathrm{C}$ attributed to oxidation of the carbonaceous residue. The total mass loss up to $760^{\circ} \mathrm{C}$ is in agreement with the formation of sodium carbonate as residue. The formation of carbonate was also confirmed by test with hydrochloric acid solution on the final residue of the TG-DSC curves.

For $\mathrm{N}_{2}$ atmosphere the anhydrous compound is stable up to $360^{\circ} \mathrm{C}$ and the mass losses occur between $360-485^{\circ} \mathrm{C}$ and $485-800{ }^{\circ} \mathrm{C}$, with loss of $30.30 \%$ and $24.28 \%$, corresponding to a small endothermic peak at $450^{\circ} \mathrm{C}$ attributed to the decomposition. No thermal event corresponding to the second mass loss is observed in the DSC curve, although the mass loss is still being observed up to $800^{\circ} \mathrm{C}$. The sharp endothermic peak at $298^{\circ} \mathrm{C}$, without mass loss in the TG curve is attributed to fusion of the compound.

For both atmospheres the DSC curve show two endothermic peaks at 99.7 with shoulder at $109.3^{\circ} \mathrm{C}$ and $298.3^{\circ} \mathrm{C}$ (air) or $99.3^{\circ} \mathrm{C}$ with shoulder at 109.3 and $298.0^{\circ} \mathrm{C}\left(\mathrm{N}_{2}\right)$ attributed to dehydration and melting of the compounds. The dehydration enthalpy found was 15.0 and $15.8 \mathrm{~kJ} \mathrm{~mol}^{-1}$, as well as the fusion enthalpy was 14.6 and $15.8 \mathrm{~kJ} \mathrm{~mol}^{-1}$, respectively. 
Table 1

Analytical and thermoanalytical $(\mathrm{TG})^{*}$ data in dry air atmosphere for the $\operatorname{Ln}(\mathrm{L})_{3}$ compounds. $\operatorname{Ln}=$ lanthanides, $\mathrm{L}=$ picolinate.

\begin{tabular}{|c|c|c|c|c|c|c|c|c|c|c|c|c|c|c|c|}
\hline \multirow[t]{2}{*}{ Compound } & \multicolumn{3}{|c|}{ Metal oxide (\%) } & \multicolumn{2}{|c|}{ L (Lost) (\%) } & \multicolumn{3}{|l|}{$C(\%)$} & \multicolumn{3}{|l|}{$\mathrm{N} / \%$} & \multicolumn{3}{|l|}{$\mathrm{H} / \%$} & \multirow[t]{2}{*}{ Final Residue } \\
\hline & Calc. & EDTA & TG & Calc. & TG & Calc. & EA & TG & Calc. & EA & TG & Calc. & EA & TG & \\
\hline $\mathrm{La}(\mathrm{L})_{3}$ & 32.34 & 32.4 & 31.52 & 67.76 & 68.48 & 42.79 & 42.96 & 42.24 & 8.32 & 8.29 & 8.41 & 2.4 & 2.42 & 2.43 & $\mathrm{La}_{2} \mathrm{O}_{3}$ \\
\hline $\mathrm{Ce}(\mathrm{L})_{3}$ & 33.99 & 33.81 & 34.2 & 66.01 & 65.8 & 42.69 & 42.5 & 42.55 & 8.3 & 8.47 & 8.27 & 2.39 & 2.45 & 2.38 & $\mathrm{CeO}_{2}$ \\
\hline $\operatorname{Pr}(\mathrm{L})_{3}$ & 33.56 & 33.73 & 33.77 & 66.44 & 66.23 & 42.62 & 42.77 & 42.63 & 8.29 & 8.64 & 8.26 & 2.39 & 2.3 & 2.38 & $\operatorname{Pr}_{6} \mathrm{O}_{11}$ \\
\hline $\mathrm{Nd}(\mathrm{L})_{3}$ & 32.95 & 32.76 & 32.66 & 67.05 & 67.34 & 42.34 & 42.67 & 42.52 & 8.23 & 8.45 & 8.27 & 2.37 & 2.25 & 2.38 & $\mathrm{Nd}_{2} \mathrm{O}_{3}$ \\
\hline $\mathrm{Sm}(\mathrm{L})_{2}$ & 33.74 & 33.99 & 34.16 & 66.26 & 65.84 & 41.84 & 41.67 & 41.57 & 8.13 & 7.85 & 8.08 & 2.35 & 2.42 & 2.34 & $\mathrm{Sm}_{2} \mathrm{O}_{3}$ \\
\hline $\mathrm{Eu}(\mathrm{L})_{3}$ & 33.31 & 33.42 & 33.25 & 66.69 & 66.75 & 41.71 & 41.48 & 41.75 & 8.11 & 8.32 & 8.12 & 2.34 & 2.42 & 2.34 & $\mathrm{Eu}_{2} \mathrm{O}_{3}$ \\
\hline $\mathrm{Gd}(\mathrm{L})_{3}$ & 34.62 & 34.38 & 34.15 & 65.38 & 65.85 & 41.29 & 41.64 & 42.22 & 8.03 & 8.32 & 8.09 & 2.31 & 2.25 & 2.33 & $\mathrm{Gd}_{2} \mathrm{O}_{3}$ \\
\hline
\end{tabular}

* TG in dry air atmosphere, $\mathrm{Ln}=$ lanthanides, $\mathrm{L}=$ picolinate.

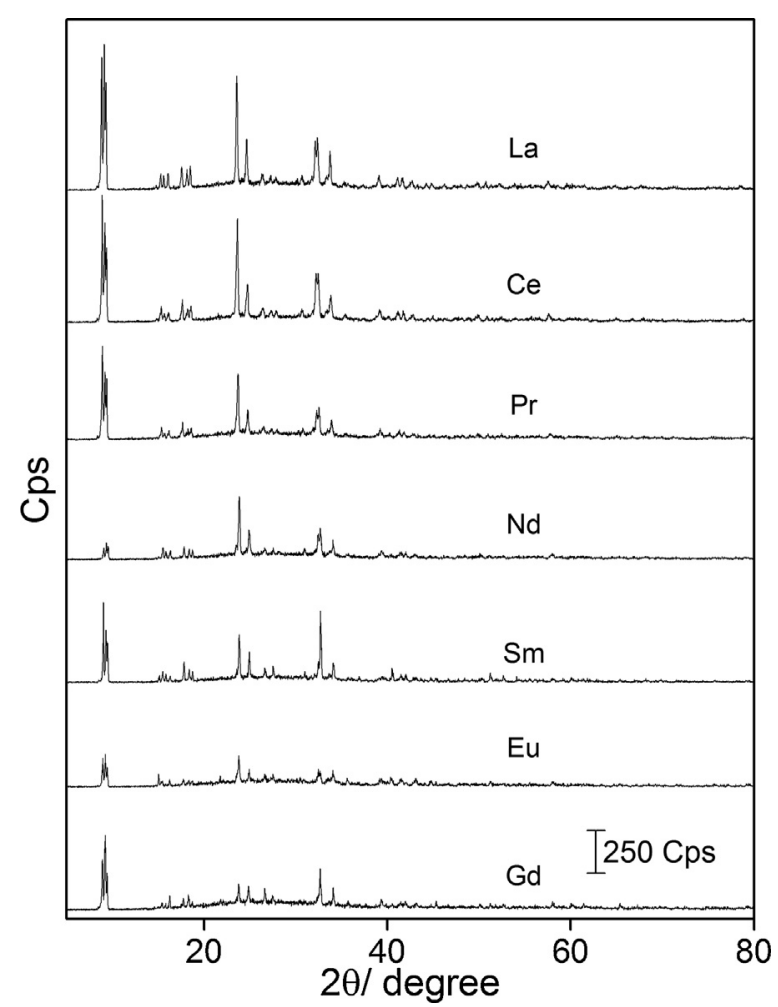

Fig. 3. X-ray powder diffraction patterns of the compounds.

\subsection{Lanthanide complexes}

\subsubsection{Analytical results}

The analytical and thermoanalytical (TG) data are shown in Table 1. Calculation based on mass losses observed in the TG curves of the lanthanum to gadolinium compounds, except promethium are in agreement with the formation of the respective oxides, and in agreement with the literature data [31-35]. From these results, it could be established the stoichiometry of the compounds, which are in agreement with the general formula $\operatorname{Ln}(\mathrm{L})_{3}$, where $\operatorname{Ln}$ represents light trivalent lanthanides (La to $\mathrm{Gd}$, except $\mathrm{Pm}$ ) and $\mathrm{L}$ is picolinate.

\subsection{2. $X R D$}

The $\mathrm{X}$ - ray diffraction powder patterns, Fig. 3, show that all the compounds have crystalline structure and $\mathrm{La}, \mathrm{Ce}, \mathrm{Pr}$ and Sm, with evidence for formation of isomorphous compound. The crystallinity of these compounds follows the order: $\mathrm{La}=\mathrm{Ce}>\mathrm{Pr}=\mathrm{Sm}>\mathrm{Nd}>\mathrm{Gd}>\mathrm{Eu}$. The difference in the crystallinity of these compounds must be due to the precipitation conditions which were not controlled.

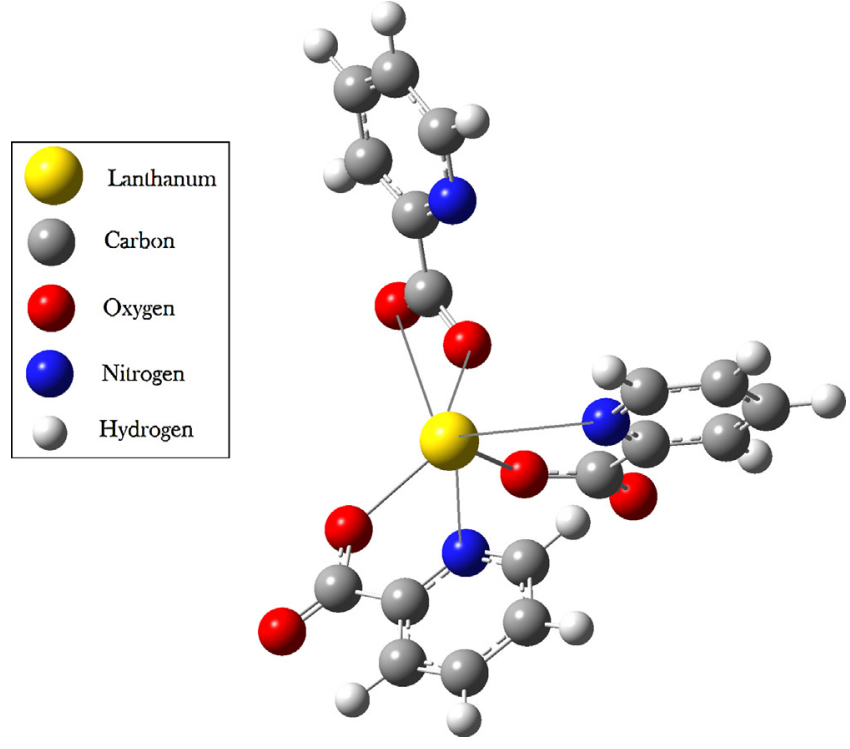

Fig. 4. Theoretical 3D structure of $\mathrm{La}\left(\mathrm{C}_{6} \mathrm{H}_{4} \mathrm{NO}_{2}\right)_{3}$ compound.

Table 2

Spectroscopic data for sodium picolinate and compounds with some light trivalent lanthanide metal ions considered in this work.

\begin{tabular}{llll}
\hline Compounds & $v_{\text {as }}\left(\mathrm{COO}^{-}\right) \mathrm{cm}^{-1}$ & $v_{\mathrm{s}}\left(\mathrm{COO}^{-}\right) \mathrm{cm}^{-1}$ & $\Delta \nu \mathrm{cm}^{-1}$ \\
\hline $\mathrm{NaL}$ & $1564 \mathrm{~s}$ & $1390 \mathrm{~s}$ & 174 \\
$\mathrm{La}(\mathrm{L})_{3}$ & $1651 \mathrm{~s}$ & $1338 \mathrm{~s}$ & 313 \\
$\mathrm{Ce}(\mathrm{L})_{3}$ & $1652 \mathrm{~s}$ & $1340 \mathrm{~s}$ & 312 \\
$\mathrm{Pr}(\mathrm{L})_{3}$ & $1654 \mathrm{~m}$ & $1340 \mathrm{~m}$ & 314 \\
$\mathrm{Nd}(\mathrm{L})_{3}$ & $1655 \mathrm{~m}$ & $1342 \mathrm{~m}$ & 313 \\
$\mathrm{Sm}(\mathrm{L})_{3}$ & $1657 \mathrm{~m}$ & $1343 \mathrm{~m}$ & 314 \\
$\mathrm{Eu}(\mathrm{L})_{3}$ & $1659 \mathrm{~m}$ & $1344 \mathrm{~m}$ & 315 \\
$\mathrm{Gd}(\mathrm{L})_{3}$ & $1659 \mathrm{~m}$ & $1345 \mathrm{~m}$ & 314
\end{tabular}

$\mathrm{L}=$ picotinate; $\mathrm{s}=$ strong; $\mathrm{m}=$ medium.

$v_{\text {as }}\left(\mathrm{COO}^{-}\right)=$antisymmetric carboxyl stretching frequency.

$v_{\mathrm{s}}\left(\mathrm{COO}^{-}\right)=$symmetric carboxyl stretching frequency.

$\Delta v=$ difference between $v_{\text {as }}\left(\mathrm{COO}^{-}\right)$and $v_{\mathrm{s}}\left(\mathrm{COO}^{-}\right)$frequencies.

\subsubsection{Infrared vibrational spectroscopy and theoretical calculations}

The bands observed in FTIR spectra for sodium picolinate and the metal ions considered in this work are shown in Table 2 and FTIR spectra are shown in supplementary material (Fig. 1S). The bands centered at $1564 \mathrm{~cm}^{-1}$ and $1389 \mathrm{~cm}^{-1}$ were assigned to antisymmetric $\left(v_{\mathrm{as}} \mathrm{COO}^{-}\right)$and symmetric $\left(v_{\mathrm{s}} \mathrm{COO}^{-}\right)$carboxyl stretching frequencies, respectively [36]. The values of $\Delta v\left(v_{\mathrm{as}} \mathrm{COO}^{-}-v_{\mathrm{s}}\right.$ $\mathrm{COO}^{-}$) for the synthesized compounds are much larger than those ones calculated for the sodium salt, suggesting that the coordination is carried out through the carboxylate group of the picolinate in a monodentate mode [37], in agreement with Tamer et al. [26]. 
The calculation of the density functional theory was performed for the $\mathrm{La}\left(\mathrm{C}_{6} \mathrm{H}_{4} \mathrm{NO}_{2}\right)_{3}$ compound. The optimized structure is shown in Fig. 4, as representative of the other compounds. The minimum calculated energy was $-5.982 \times 10^{6} \mathrm{kcal} \mathrm{mol}^{-1}$, corresponding to the structure of Fig. 4. The conformation of the molecule suggests that the two picolinates act as monodentate ligands in relation to the carboxylate group and the third picolinate in a bidentate mode probably due to steric hindrance.

The optimized molecular structure data suggest that linkage also occurs by the nitrogen atom of the pyridine ring when picolinate acts as monodentate, i.e., the coordination of the ligand to the metal occurs by both nitrogen and oxygen atoms forming a chelate. As a result of this coordination, the electron density in the picolinate ligand shifts toward the pyridine $\mathrm{N}$ atom, leading to some increase in the $\mathrm{CN}$ stretching vibration wavenumber. This shift is attributed to either an inductive effect or a combination of inductive effect and resonance, and leads to an increase in the double bond character of the carbonyl group and a shift of the stretching wavenumber of $\mathrm{CO}$ moiety to a higher value [26].

The comparison of experimental (most stable) and theoretical FTIR spectra are presented in Fig. $5 a$ and b, respectively. There is a great similarity between the experimental and theoretical spectrum and bond lengths and angles are in agreement with the values reported in the literature, since the calculations are based on complex in gaseous state.

\subsubsection{Thermal analysis (TG-DSC and EGA)}

The simultaneous TG-DSC curves of the compounds in dry air and nitrogen atmospheres are shown in Fig. 6(a-g) and Fig. 7(a-g), respectively. These curves show that all the compounds were obtained in the anhydrous state and that the mass losses occur in a single (Ce), two ( $\mathrm{La}, \mathrm{Pr}, \mathrm{Nd}, \mathrm{Sm}$ and $\mathrm{Eu}$ ) or three (Gd) steps (air) and two (Ce) or three ( $\mathrm{La}$, Pr to $\mathrm{Gd}$ ) steps $\left(\mathrm{N}_{2}\right)$ sometimes, corresponding to endothermic and exothermic peaks, but sometimes occurring without thermal events.

These curves also show that the thermal stability of these compounds (I), as well as the final temperature of the thermal decomposition (II), in both atmospheres, follows the order:

(I) $\mathrm{Pr}>\mathrm{La}=\mathrm{Nd}=\mathrm{Sm}>\mathrm{Eu}>\mathrm{Gd}>\mathrm{Ce}$

(II) $\mathrm{Gd}>\mathrm{Eu}>\mathrm{Sm}>\mathrm{Nd}>\mathrm{Pr}>\mathrm{La}>\mathrm{Ce}$

The thermal behavior of the compounds in air atmosphere is not the same in $\mathrm{N}_{2}$ one, thus the TG-DSC curves in each atmosphere are presented separately.

\subsubsection{TG-DSC in oxidative atmosphere}

The TG-DSC curves of the compounds are shown in Fig. 6(a-g). The thermal decomposition of the anhydrous compounds show that similarity of TG profiles is observed for lanthanum, neodymium, samarium and europium. On the other hand, cerium, praseodymium and gadolinium display TG profiles characteristic of each compound.

Thus, the features of each of these compounds are discussed based on their similarity.

\section{Lanthanum, neodymium, samarium and europium compounds}

The TG-DSC curves of the compounds are shown in Fig. 6(a, d, e and $\mathrm{f}$ ). The first mass loss that occurs through a fast process between $400-480^{\circ} \mathrm{C}(\mathrm{La}), 400-485^{\circ} \mathrm{C}(\mathrm{Nd}), 400-510^{\circ} \mathrm{C}(\mathrm{Sm})$ and $390-490^{\circ} \mathrm{C}$ (Eu), with loss of $60.40 \%, 60.42 \%, 61.80 \%$ and $62.93 \%$ corresponding to a large and sharp exothermic peak at $470^{\circ} \mathrm{C}, 480^{\circ} \mathrm{C}, 470^{\circ} \mathrm{C}$ and $460^{\circ} \mathrm{C}$, respectively. The exothermic peak is attributed to oxidation of the organic matter and/or of gaseous products evolved during the thermal decomposition, with the formation of carbonaceous residue and a derivative of carbonate, probably the corresponding dioxycarbonate, $\mathrm{La}_{2} \mathrm{O}_{2} \mathrm{CO}_{3}$, as already observed for other compounds with trivalent lanthanides [38]. Test with hydrochloric acid solution on sample heated up to the temperature of formation of the derivative of carbonate, as indicated by the TG-DSC curves, confirmed evolution of $\mathrm{CO}_{2}$ and presence of carbonaceous residue.

The last step that occurs through a slow process, between $480-695^{\circ} \mathrm{C}(\mathrm{La}), 485-755^{\circ} \mathrm{C}(\mathrm{Nd}), 510-770^{\circ} \mathrm{C}(\mathrm{Sm})$ and $490-790^{\circ} \mathrm{C}$ (Eu), with loss of $8.08 \%, 6,92 \%, 4,04 \%$ and $3,82 \%$ corresponding to small exothermic peak followed by on indicium of endothermic event at $590^{\circ} \mathrm{C}$ and $670^{\circ} \mathrm{C}(\mathrm{La}), 530$ and $600^{\circ} \mathrm{C}(\mathrm{Nd})$ and $575^{\circ} \mathrm{C}$ and $625^{\circ} \mathrm{C}(\mathrm{Sm})$, respectively, attributed to oxidation of the carbonaceous residue and thermal decomposition of the derivative of carbonate.

The total mass loss up to $695^{\circ} \mathrm{C}(\mathrm{La}), 755^{\circ} \mathrm{C}(\mathrm{Nd}), 770^{\circ} \mathrm{C}(\mathrm{Sm})$ and $790^{\circ} \mathrm{C}(\mathrm{Eu})$ is in agreement with the formation of the respective oxides, $\mathrm{Ln}_{2} \mathrm{O}_{3}$ ( $\left.\mathrm{Ln}=\mathrm{La}, \mathrm{Nd}, \mathrm{Sm}, \mathrm{Eu}\right)$.

\section{Cerium compound}

The TG-DSC curves of the compound are shown in Fig. 6(b). These curves show that the anhydrous compound is stable up to $350^{\circ} \mathrm{C}$, and above this temperature the thermal decomposition occurs through a fast process and in a single step with loss of $65.80 \%$, corresponding to an exothermic peak at $430^{\circ} \mathrm{C}$. The large and sharp exothermic peak is attributed to oxidation of the organic matter and/or of the gaseous products evolved during the thermal decomposition, as well as the heat contribution through oxidation reaction of $\mathrm{Ce}$ (III) to $\mathrm{Ce}(\mathrm{IV})$.

The total mass loss up to $490^{\circ} \mathrm{C}$ is in agreement with the formation of cerium (IV) oxide, $\mathrm{CeO}_{2}$, as final residue (Calc. $=66.01 \%$, TG $=65.80 \%$ ).

The smaller thermal stability as well as the final temperature of thermal decomposition of the cerium compound is attributed to the oxidation reaction of $\mathrm{Ce}$ (III) to $\mathrm{Ce}$ (IV) and of the organic matter and/or of the gaseous products evolved during the thermal decomposition. This behavior had already been observed for other cerium compounds [39].

\section{Praseodymium compound}

The TG-DSC curves of the compound are shown in Fig. 6(c). These curves show that the anhydrous compound is stable up to $405^{\circ} \mathrm{C}$, and above this temperature the thermal decomposition occurs in two consecutive steps between $405-475^{\circ} \mathrm{C}$ and $475-750^{\circ} \mathrm{C}$ with loss of $62.22 \%$ and $4.01 \%$, respectively. The large and sharp exothermic peak, corresponding to the first mass loss is attributed to the oxidation of organic matter and/or of the gaseous products evolved during the thermal decomposition, with the formation of carbonaceous residue and a derivative of carbonate. No thermal event corresponding to the second mass loss is observed in the DSC curves, probably because in this step the oxidation of the carbonaceous residue (exo) and the thermal decomposition of the carbonate derivative (endo) are not sufficient to produce a thermal event. Calculations based on the total mass loss up to $750^{\circ} \mathrm{C}$ is in agreement with the formation of praseodymium oxide, $\operatorname{Pr}_{6} \mathrm{O}_{11}$, as final residue (Calc. $=66.44 \%, \mathrm{TG}=66.23 \%$ ).

\section{Gadolinium compound}

The TG-DSC curves of the compound are shown in Fig. 6(g). These curves show that the anhydrous compound is stable up to $380^{\circ} \mathrm{C}$, and the thermal decomposition occurs in three consecu- 

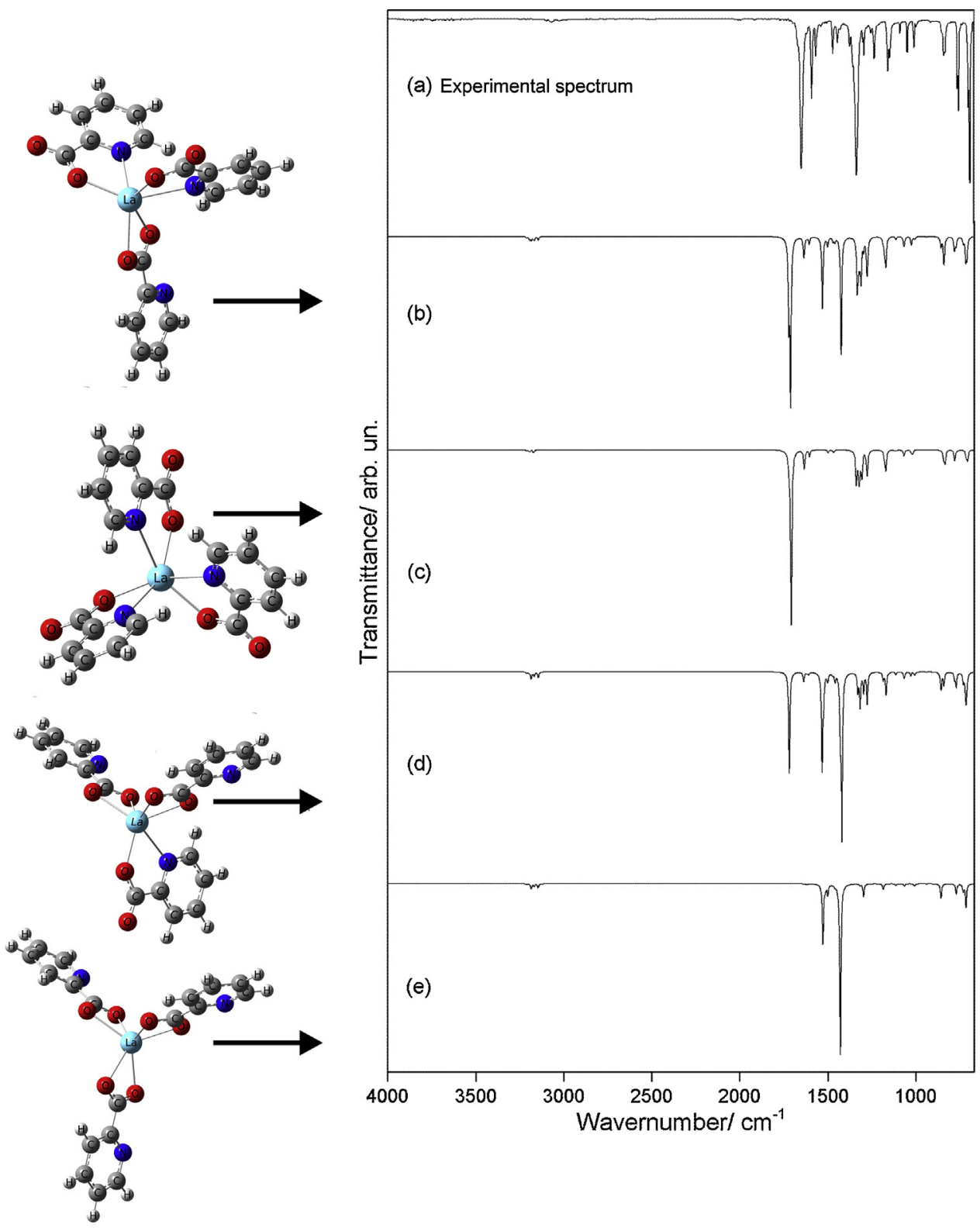

Fig. 5. Comparative experimental of FTIR and theoretical IR spectra.

tive steps, between $380-450^{\circ} \mathrm{C}, 450-520^{\circ} \mathrm{C}$ and $520-910^{\circ} \mathrm{C}$, with loss of $44.06 \%$ and $18.58 \%$ and $3.21 \%$, respectively. These curves also show that the first two steps occur through a fast process, corresponding to endothermic and exothermic peaks at $430{ }^{\circ} \mathrm{C}$ and $475^{\circ} \mathrm{C}$, respectively, attributed to the thermal decomposition and oxidation of the organic matter and/or of the gaseous products evolved during the thermal decomposition, with the formation of carbonaceous residue and carbonate derivative.

In the last step where in the mass loss occurs slowly and without thermal event in the DSC curve. Mass loss is attributed to the thermal decomposition of the carbonate derivative (endo) and oxidation of the carbonaceous residue (exo), where the net heat is not sufficient to produce a thermal event.

The total mass loss up to $910^{\circ} \mathrm{C}$, is in agreement with the formation of gadolinium oxide, $\mathrm{Gd}_{2} \mathrm{O}_{3}$, as final residue (Calc. $=65.38 \%$, TG $=65.85 \%$ ).

\subsection{TG-DSC in inert atmosphere}

The TG-DSC curves of the compounds are shown in Fig. 7(a-g). These curves show that the thermal stability of the lanthanum, praseodymium, neodymium and samarium compounds is the same in both atmospheres (air, $\mathrm{N}_{2}$ ). For the cerium, europium and gadolinium compounds the thermal stability is slightly higher in $\mathrm{N}_{2}$ than in air atmosphere.

These curves also show a great similarity in the TG curves of these compounds, except for cerium, however the similarity in the DSC curves is observed for praseodymium and neodymium or europium and gadolinium, while lanthanum and samarium display DSC profiles characteristic of each compound.

Thus, the features of each of these compounds are discussed based on the similarity of the TG curves. 


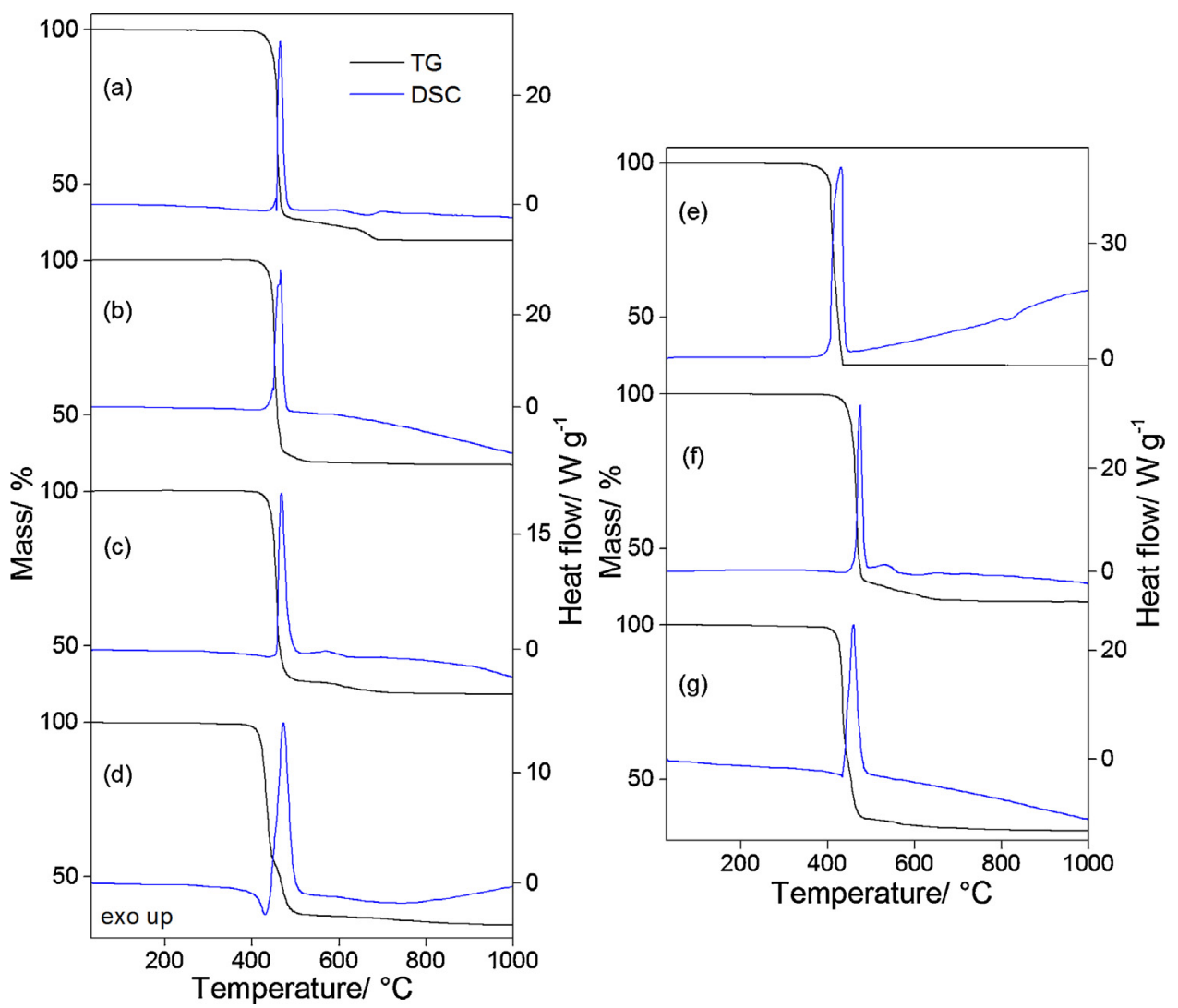

Fig. 6. TG-DSC curves in dry air atmosphere of: (a) $\mathrm{La}(\mathrm{L})_{3}, 10.469 \mathrm{mg}$; (b) $\mathrm{Ce}(\mathrm{L})_{3}, 10.499 \mathrm{mg}$; (c) $\operatorname{Pr}(\mathrm{L})_{3}, 10.453 \mathrm{mg}$; (d) $\mathrm{Nd}(\mathrm{L})_{3}, 10.447 \mathrm{mg} ;\left(\right.$ e) $\mathrm{Sm}(\mathrm{L})_{3}, 10.445 \mathrm{mg}$; (f) $\mathrm{Eu}(\mathrm{L})_{3}$, $10.482 \mathrm{mg}$; (g) Gd(L) $10.502 \mathrm{mg}$. L = nicotinate.

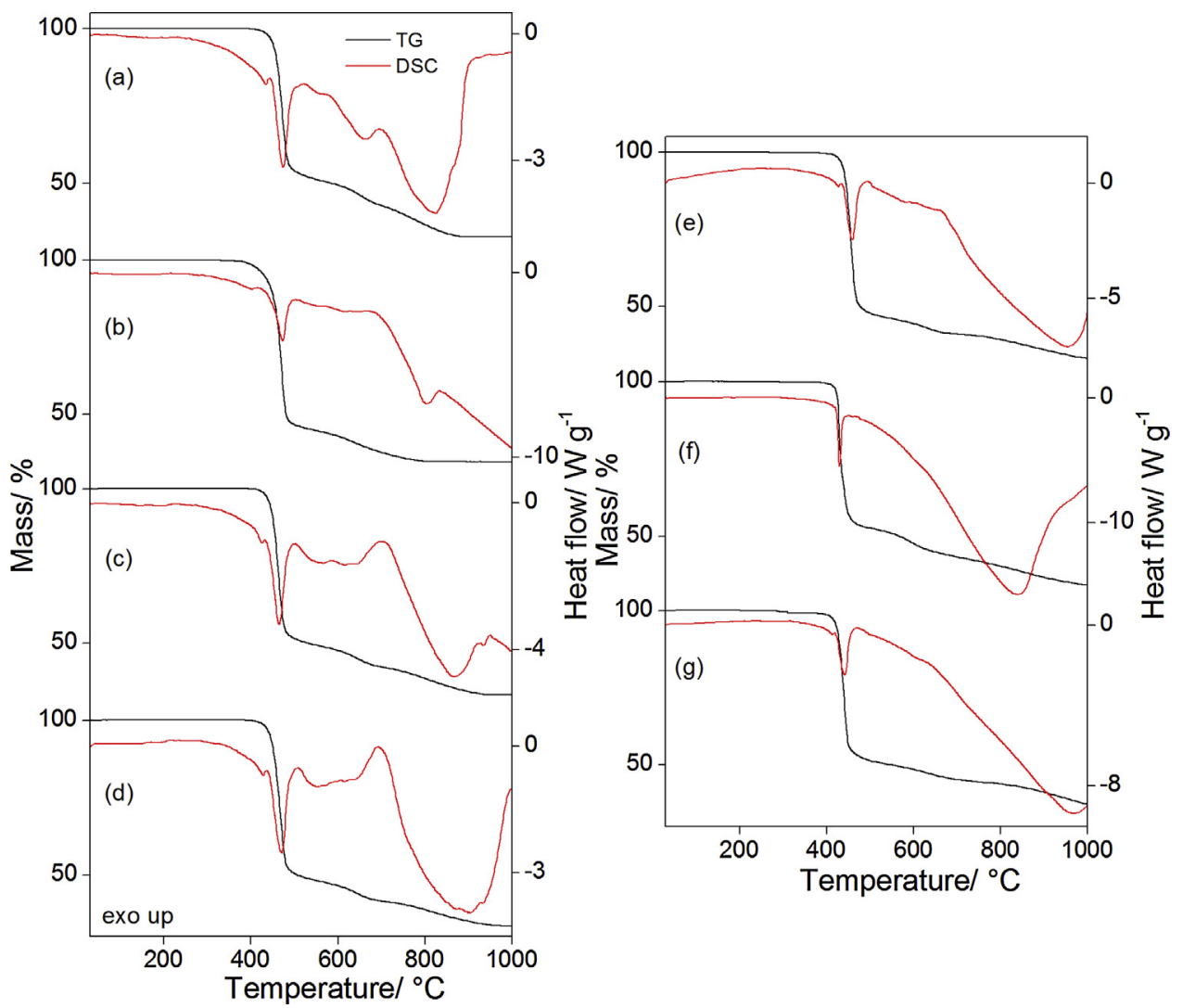

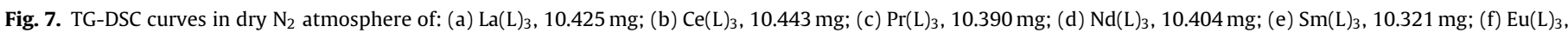
$10.418 \mathrm{mg}$; $(\mathrm{g}) \mathrm{Gd}(\mathrm{L})_{3} 10.592 \mathrm{mg}$. $\mathrm{L}=$ nicotinate 


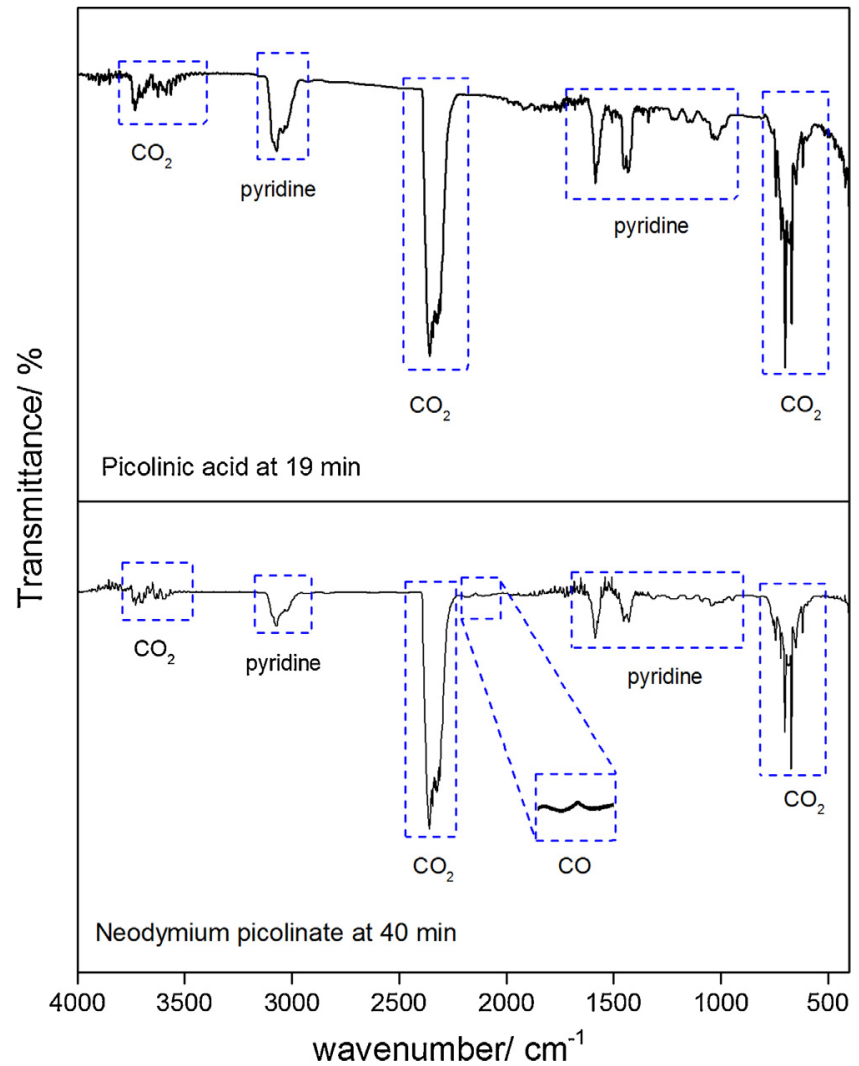

Fig. 8. FTIR spectra from gaseous products evolved during the thermal decomposition of picolinic acid and neodymium compound as representative of all the compounds.

\section{Cerium compound}

The TG-DSC curves of the compound are shown in Fig. 7 (b). These curves show mass losses in two consecutive steps, between $355-800^{\circ} \mathrm{C}$. The first step, occurring up to $490^{\circ} \mathrm{C}$ and through a fast process, with loss of $52.75 \%$, corresponds to an endothermic peak at $475^{\circ} \mathrm{C}$ and is attributed to the thermal decomposition with the formation of carbonaceous residue. The second step, between 490 and $800^{\circ} \mathrm{C}$, occurs slowly, with loss of $12.77 \%$. It correspond to an endothermic peak at $800^{\circ} \mathrm{C}$ and is attributed to the pyrolysis of the carbonaceous residue, with the formation of cerium (IV) oxide, $\mathrm{CeO}_{2}$, as final residue.

\section{Lanthanum, praseodymium to gadolinium compounds}

The TG-DSC curves of the compounds are shown in Fig. 7(a, c-g). These curves show mass losses in three consecutive steps, between $400-500^{\circ} \mathrm{C}, 500-675^{\circ} \mathrm{C}$ and $675-880^{\circ} \mathrm{C}(\mathrm{La}) ; 405-485^{\circ} \mathrm{C}$, $485-680^{\circ} \mathrm{C}$ and $680-935^{\circ} \mathrm{C}(\mathrm{Pr}) ; 400-495^{\circ} \mathrm{C}, 495-675^{\circ} \mathrm{C}$ and $675-960^{\circ} \mathrm{C}(\mathrm{Nd}) ; 400-495^{\circ} \mathrm{C}, 495-680^{\circ} \mathrm{C}$ and $680-995^{\circ} \mathrm{C}(\mathrm{Sm})$; $395-480^{\circ} \mathrm{C}, 480-670^{\circ} \mathrm{C}$ and $670-1000^{\circ} \mathrm{C}(\mathrm{Eu})$ and $390-500^{\circ} \mathrm{C}$, $500-715^{\circ} \mathrm{C}$ and $715-1000^{\circ} \mathrm{C}(\mathrm{Gd})$, with losses of $45.63 \%, 10.28 \%$ and $11.48 \%(\mathrm{La}) ; 46.89 \%, 10.25 \%$ and $9.66 \%(\mathrm{Pr}) ; 48.86 \%, 9.04 \%$ and $8.67 \%(\mathrm{Nd}) ; 52.05 \%, 6.75 \%$ and $8.07 \%(\mathrm{Sm}) ; 46.88 \%, 9.01 \%$ and $10.04 \%$ (Eu); $48.66 \%, 6.72 \%$ and $7.84 \%(\mathrm{Gd})$, corresponding to endothermic peaks at $475^{\circ} \mathrm{C}, 665^{\circ} \mathrm{C}, 825^{\circ} \mathrm{C}(\mathrm{La}) ; 465^{\circ} \mathrm{C}, 560^{\circ} \mathrm{C}, 865^{\circ} \mathrm{C}(\mathrm{Pr})$; $470^{\circ} \mathrm{C}, 560^{\circ} \mathrm{C}, 900^{\circ} \mathrm{C}(\mathrm{Nd}) ; 460^{\circ} \mathrm{C}, 950^{\circ} \mathrm{C}(\mathrm{Sm}) ; 450^{\circ} \mathrm{C}, 890^{\circ} \mathrm{C}(\mathrm{Eu})$ and $445^{\circ} \mathrm{C}, 965^{\circ} \mathrm{C}(\mathrm{Gd})$. In all the compounds, the first mass loss occurs through a fast process corresponding to a sharp endothermic peak, and is attributed to the thermal decomposition, with the formation of carbonaceous residue.
The last two steps, that occur slowly corresponding to endothermic peaks or without thermal event are attributed to the pyrolysis of the carbonaceous residue, with the formation of the respective oxides, $\mathrm{Pr}_{6} \mathrm{O}_{11}, \mathrm{Ln}_{2} \mathrm{O}_{3}$ ( $\mathrm{Ln}=\mathrm{La}, \mathrm{Nd}, \mathrm{Sm}$ and $\mathrm{Eu}$ ). For gadolinium compound, mass loss continues to be observed up to $1000^{\circ} \mathrm{C}$.

\subsection{Evolved gas analysis (EGA)}

The gaseous products evolved during the thermal decomposition of picolinic acid and its sodium salt as well as of the compounds synthesized in this work were monitored by FTIR. The main gaseous products were pyridine and $\mathrm{CO}_{2}$ for picolinic acid or pyridine and $\mathrm{CO}$ and $\mathrm{CO}_{2}$ for the other compounds, in both atmospheres. The FTIR spectra of the gaseous products evolved during the thermal decomposition of picolinic acid and neodymium picolinate as representative of all the compounds are shown in Fig. 8.

\section{Conclusion}

From the TG, complexometry and elemental analysis results a general formula could be established for the synthesized compounds.

The X-ray power patterns showed that all the compounds have a crystalline structure, with evidence of isomorphism between lanthanum and cerium or praseodymium and samarium compounds.

The experimental infrared spectroscopic data suggest that the picolinate acts as a monodentade with respect to the carboxylate group, suggesting that the $\mathrm{N}$ atom of the pyridine ring also participates in the coordination towards the metal ions. However, the calculation of the density functional theory and theoretical IR spectroscopic data suggest that the ligand acts as a monodentade with respect to the carboxylate group in two of the three bonds, and the third as a bidentade mode probably due to steric hindrance.

The simultaneous TG-DSC and DSC curves provided previously unreported information concerning the thermal stability and thermal decomposition of these compounds in dynamic dry air and $\mathrm{N}_{2}$ atmosphere. Although, the thermal behavior of the compounds is dependent on the nature of the metal ion, the gaseous products evolved during the thermal decomposition of the picolinate (sodium salt) and its compounds studied in this work were the same, i.e, pyridine, carbon monoxide and carbon dioxide, in both atmospheres. For the picolinic acid in both atmospheres only pyridine and carbon dioxide were also detected.

\section{Acknowledgments}

The authors thanks FAPESP (Proc. 2013/09022-7), CNPq and CAPES Foundations (Brazil) for financial support. This research was supported by resources supplied by the Center for Scientific Computing (NCC/GridUNESP) of the Sao Paulo State University (UNESP), Instituto de. Quimica de Araraquara, UNESP Campus de Araraquara and CENAPAD-UNICAMP.

\section{Appendix A. Supplementary data}

Supplementary data associated with this article can be found, in the online version, at http://dx.doi.org/10.1016/j.jaap.2016.01.010.

\section{References}

[1] H. Tomioka, T. Shimizu, Y. Tatano, Effects of picolinic acid on the antimicrobial functions of host macrophages against Mycobacterium avium complex, Int. J. Antimicrob. Agents 29 (2007) 460-464.

[2] R.S. Grant, S.E. Coggan, G.A. Smythe, The physiological action of picolinic acid in the human brain, Int. J. Tryptophan Res. 2 (2009) 71-79.

[3] S. Cai, K. Sato, T. Shimizu, S. Yamabe, M. Hiraki, C. Sano, et al., Antimicrobial activity of picolinic acid against extracellular and intracellular Mycobacterium 
avium complex and its combined activity with clarithromycin, rifampicin and fluoroquinolones, J. Antimicrob. Chemother. 57 (2006) 85-93.

[4] E. Blasi, R. Mazzolla, L. Pitzurra, R. Barluzzi, F. Bistoni, Protective effect of picolinic acid on mice intracerebrally infected with lethal doses of Candida albicans, Antimicrob. Agents Chemother. 37 (1993) 2422-2426.

[5] J.A. Fernandez-Pol, D.J. Klos, P.D. Hamilton, Antiviral, cytotoxic and apoptotic activities of picolinic acid on human immunodefi ciency virus- 1 and human herpes simplex virus-2 infected cells, Anticancer Res. 21 (2001) 3773-3776.

[6] A. Ramautar, M. Mabandla, J. Blackburn, W.M.U. Daniels, Inhibition of HIV-1 tat-induced transactivation and apoptosis by the divalent metal chelators, fusaric acid and picolinic acid-Implications for HIV-1 dementia, Neurosci. Res. 74 (2012) 59-63.

[7] S.A. Boyd, R.E. Kohrman, D.X. West, Transition metal ion complexes of 2-picolinate N-oxide, J. Inorg. Nucl. Chem. 38 (1976) 607-608.

[8] Boyd S.A., Kohrman R.E., West D.X., Inorg. Nucl. Chem. Letters. Pergamon Press, Printed in Great Britain, 1976, 12, 603-608.

[9] S. Lis, Z. Piskuła, M. Kubicki, The structure and spectroscopy of lanthanide(III) complexes with picolinic acid $\mathrm{N}$-oxide in solution and in the solid state, Mater. Chem. Phys. 114 (2009) 134-138.

[10] D. Xu, Y. Xu, N. Cheng, X. Zhou, Y. Shi, Q. He, Synthesis, characterization, and biological studies of lanthanide complexes with 2,6-pyridine dicarboxylic acid and $\alpha$-picolinic acid, J. Coord. Chem. 63 (2010) 2360-2369.

[11] P.I. Girginova, F.A. Almeida Paz, P.C.R. Soares-Santos, R.A. Sá Ferreira, L.D. Carlos, V.S. Amaral, et al., Synthesis, characterisation and luminescent properties of lanthanide-organic polymers with picolinic and glutaric acids, Eur. J. Inorg. Chem. (2007) 4238-4246.

[12] L. Moyne, G. Thomas, Etude thermogravimtrique des picolates et dipicotates de lanthane, praséodyme et néodyme, Anal. Chim. Acta 29 (1963) 66-69.

[13] Y.J. Park, B.H. Lee, W.H. Kim, Y. Do, Investigation of coordinational properties of Europium(III) complexes with picolinic acid using Eu(III) excitation spectroscopy, J. Colloid Interface Sci. 209 (2000) 268-270.

[14] W. Li, X.-L. Wang, X.-Y. Song, L.-C. Li, D.-Z. Liao, Z.-H. Jiang, Crystal structures, magnetic and photoluminescent properties of one-dimensional lanthanide complexes with picolinate ligand, J. Mol. Struct. 885 (2008) 1-6.

[15] P. Press, G. Britain, Chemistry A, 34, Pergamon Press, Great Britain, 1972, pp. $1851-1855$.

[16] N.B. Keck, N.J. Hornung, W.G. Bos, The preparation and characterization of some rare earth picolinate complexes, J. Inorg. Nucl. Chem. 36 (1974) $1521-1525$.

[17] A.C. Gigante, D.J.C. Gomes, L.S. Lima, F.J. Caires, O. Treu-Filho, M. Ionashiro, Synthesis, thermal properties and spectroscopic study of solid mandelate of light trivalent lanthanides, Thermochim. Acta. 536 (2012) 6-14.

[18] H.A. Flaschka, EDTA Titrations and Introduction to Theory and Practice, 2nd ed., Pergamon Press Oxford, 1967.

[19] M. Ionashiro, C.A.F. Graner, J. Zuanon Netto, Titulacão complexométrica de lantanídeos e ítrio, Ecl. Quim. 8 (1983) 29-32.

[20] A.D. Becke, Density-functional thermochemistry: III. The role of exact exchange, J. Chem. Phys. 98 (1993) 5648.

[21] C. Lee, C. Hill, R.G. Parr, Developement of the Colle-Salvetti correlation-energy formula into a functional of the electron density, Phys. Rev. B 37 (1988) 785-789.

[22] O. Treu-Filho, J.C. Pinheiro, E.B. da Costa, J.E.V. Ferreira, A.F. de Figueiredo, R.T. Kondo, et al., Experimental and theoretical study of the compound [Pd(dmba)(NCO)(imz)], J. Mol. Struct. 829 (2007) 195-201.

[23] O.T. Filho, J.C. Pinheiro, R.T. Kondo, Designing Gaussian basis sets to the theoretical study of the piezoelectric effect of perovskite $\left(\mathrm{BaTiO}_{3}\right)$, J. Mol. Struct. Theochem. 671 (2004) 71-75.
[24] M.J. Frisch, G.W. Trucks, H.B. Schlegel, G.E. Scuseria, M.A. Robb, J.R. Cheeseman, G. Scalmani, V. Barone, B. Mennucci, G.A. Petersson, H. Nakatsuji, M. Caricato, X. Li, H.P. Hratchian, A.F. Izmaylov, J. Bloino, G. Zheng, J.L. Sonnenberg, M. Hada, M. Ehara, K. Toyota, R. Fukuda, J. Hasegawa, M. Ishida, T. Nakajima, Y. Honda, O. Kitao, H. Nakai, T. Vreven, J.A. MontgomeryJr., J.E. Peralta, F. Ogliaro, M. Bearpark, J.J. Heyd, E. Brothers, K.N. Kudin, V.N. Staroverov, R. Kobayashi, J. Normand, K. Raghavachari, A. Rendell, J.C. Burant, S.S. Iyengar, J. Tomasi, M. Cossi, N. Rega, N.J. Millam, M. Klene, J.E. Knox, J.B. Cross, V. Bakken, C. Adamo, J. Jaramillo, R. Gomperts, R.E. Stratmann, O. Yazyev, A.J. Austin, R. Cammi, C. Pomelli, J.W. Ochterski, R.L. Martin, K. Morokuma, V.G. Zakrzewski, G.A. Voth, P. Salvador, J.J. Dannenberg, S. Dapprich, A.D. Daniels, O. Farkas, J.B. Foresman, J.V. Ortiz, J. Cioslowski, D.J. Fox, Gaussian 09 Revision A.02., 2009.

[25] D. Goodson, S.K. Sarpal, P. Bopp, M. Wohsberg, Influence on Isotope Effect Calculatlons of the Method of Obtaining Force Constants From Vibrational Datat, 1982, 64.

[26] Ö. Tamer, D. Avci, Y. Atalay, Synthesis, X-ray structure, spectroscopic characterization and nonlinear optical properties of Nickel (II) complex with picolinate: A combined experimental and theoretical study, J. Mol. Struct. 1098 (2015) 12-20.

[27] H.B. Schelegel, New Theoretical Concepts for Understanding Organic Reactions, in: J. Bertran (Ed.), Academic, The Netherlands, 1989.

[28] R. Dennington, T. Keith, J. Millam, GaussView, 2015, Version 5.0.8.

[29] J.R. Allan, W.C. Geddes, C.S. Hindle, A.E. Orr, Thermal analysis studies on pyridine carboxylic acid complexes of zinc (II), Thermochim. Acta 153 (1989) 249-256.

[30] D.Q.M. Craig, Mike Reading Thermal Analysis of Pharmaceuticals, CRC Press-Taylor \& Francis Group, 2007, pp. 35.

[31] A.M.G. Hussein, Rare earth metal oxides: formation, characterization and catalytic activity Thermoanalytical and applied pyrolysis review, J. Anal. Appl. Pyrolysis 37 (1996) 111-149.

[32] A.M.G. Hussein, Formation of praseodymium oxide from the thermal decomposition of hydrated praseodymium acetate and oxalate, J. Anal. Appl. Pyrolysis 29 (1994) 89-102.

[33] T.A.D. Colman, D.J.C. Gomes, F.J. Caires, O.T. Filho, R.D.C. da Silva, M. Ionashiro, Synthesis, evolved gas analysis (EGA) during pyrolysis and spectroscopic study of light lanthanide nicotinate insolid state, J. Anal. Appl. Pyrolysis 111 (2015) 132-139.

[34] R. Łyszczek, Thermal investigation and infrared evolved gas analysis of light lanthanide(III) complexes with pyridine-3,5-dicarboxylic acid, J. Anal. Appl. Pyrolysis 86 (2009) 239-244.

[35] R. Łyszczek, A. Ostasz, A. Bartyzel, A. Lipke, Thermal, spectroscopic and luminescence investigations of lanthanide(III) coordination polymers based on V-shaped 4,4'-sulfonyldibenzoic acid, J. Anal. Appl. Pyrolysis 115 (2015) $370-378$.

[36] K. Nakamoto, Infrared and Raman Spectra of Inorganic and Coordination Compounds. Part B, 5th ed., Wiley, New York, 1997, pp. 58-61.

[37] G.B. Deacon, R.J. Phillips, Coord. Chem. Rev. 33 (1980) 227-250

[38] F.J. Caires, L.S. Lima, D.J.C. Gomes, A.C. Gigante, O. Treu-Filho, M. Ionashiro, Thermal and spectroscopic studies of solid oxamate of light trivalent lanthanides, J. Therm. Anal. Calorim. 111 (2013) 349-355. 